\title{
Patients' opinion and perception survey of community pharmacists in Republic of Macedonia
}

\author{
Maja Simonoska Crcarevska*, Nikola Geskovski, Marija Glavas Dodov, \\ Tatjana Sterjeva, Kristina Karadzinska, Renata Slaveska Raicki \\ Institute of pharmaceutical technology, Faculty of pharmacy, \\ Ss. Cyril and Methodius University, Majka Tereza 47, 1000 Skopje, R. Macedonia
}

Received: November 2017; Accepted: January 2018

\begin{abstract}
Over the past decade, numerous changes have taken place across the community pharmacy (CP) sector in the Republic of Macedonia (RM). The overall aim of this study is to analyze patients` perception and opinion regarding the Community pharmacy sector and its recognizable role in health care system in RM. Additionally, this study focusses on factors affecting patients choice of the certain $\mathrm{CP}$ and perception of the quality of the $\mathrm{CP}$ premises. The survey covered randomly selected patients of those visiting community pharmacies in all 8 regions of the country. An anonymous semi-open questionnaire consisting of 21 items was structured, which covered three main groups of questions related to: socio-demographic factors of the respondents, reasons influencing respondents` choice of the certain CP and respondents' opinion and impressions of community pharmacists`expertise and quality of offered services in CP settings. The obtained results have confirmed that $69.82 \%$ of respondents showed loyalty to the same CP. These findings were supported by tree main reasons: (1) the pharmacist and professional staff working in certain CP (74.19\%), (2) CP keeps up a satisfactory supply (69.68\%) and (3) CP is situated in a convenient location (61.94\%). The overall patients' perception of elements of pharmaceutical care services provided in $\mathrm{CP}$ was that they are on a high level (above 80\%). Despite the encouraging results obtained, this study can serve as a core element for continuous monitoring and quality improvement of the national CPs network in near future.
\end{abstract}

Keywords: community pharmacists, pharmaceutical care, patients' opinion and perception

\section{Introduction}

The pharmaceutical sector is an essential element of the healthcare system that has direct contribution to the improvement of population health and positive health outcomes. In continuum, we are witnessing that pharmacy profession and community pharmacy practice in Republic of Macedonia (RM) follow the global trends in the constant evolution and changes that have been happening almost on a daily basis. This dynamic is determined by many factors and largely by public health needs and expectations, followed by the development of health technologies, modern therapies, and innovative products, and is also coupled with changes in policy and regulation needed to support sustainability of a modern pharmaceutical sector. As acknowledged, community pharmacies reflect the pharmacy profession through the provision of a range of healthcare services and activities. Pharmaceutical services and activities according to the Law on Healthcare (2012) of RM, Article 15, item 37, are defined as part of the healthcare services and activities that encompass constant, continuous supply of medicines and medical devices; medicine compounding, manufacturing, distribution, quality control, as well as

\footnotetext{
*msimonoska@ff.ukim.edu.mk
} 
advising, counseling, consulting and educating patients and healthcare professionals about the rational and efficient use of medicines and medical devices and hence, monitoring the effects of medicines usage. Under the same Law (Article 89) all professional activities that pharmacists provide in the CPs are closely defined. More specifically, portfolio of services provided covers procurement, setting, storage, dispensing, testing and quality control of medicines, hygiene and medical supplies and active medicine substances. Moreover, pharmacists can also compound extemporaneous (magistral) and galenic products. Core elements of Article 89 further emphasize the pharmacists' role in patient care. In addition to the abovementioned activities, pharmacists can procure and dispense supplies for children's and dietary nutrition, orthopedic devices, equipment and medical instruments.

These comprehensive definitions are in correlation with one of the key change in pharmaceutical profession that occurred nearly three decades ago (in 1990) when Hepler and Strand (1990) set the foundations for a patientfocused role of pharmacists and urged pharmacists to accept and implement pharmaceutical care as a professional mission, in which the role of pharmacists from professionals for compounding and dispensing medicines will be extended to healthcare professionals that will be responsible for safe, effective and rational use of medicines.

Speaking in general, only recently (10 years ago) all community pharmacies (CPs) in RM have been privatized (Stavrova et al., 2016). In February 2016 in RM there were $846 \mathrm{CPs}$ out of 1019 registered pharmacies (Arsovska et al., 2016, Stavrova et al., 2016). In the same period, at the Pharmaceutical Chamber of Macedonia 2413 licensed pharmacists were registered (Arsovska et al., 2016) or 11.65 pharmacists per 10,000 inhabitants according to the estimated population number for 2015 (www.stat.gov.mk). The situation was similar in 2012 when the Republic of Macedonia according to the FIP analysis was the $17^{\text {th }}$ out of 82 countries in terms of this data (Gal, 2012). If compared to the data presented by Anderson, 2007, there is high upgrade in this term, as in 2004 there were 15 pharmacists per 100,000 population, or normalized 1.5 per 10,000 population. As it was noted in Arsovska et al. (2016) 46\% of all pharmacists were employed at CPs. Compared to Europe, RM is below the average of $70 \%$, although it has to be pointed that there are great variances between countries, with lowest value noted in Denmark ( 18\%) and highest in Austria ( 90\%) (Chan and Wuliji, 2006). Estimated number of pharmacists employed in CPs per 100,000 population was 53, and compared to data for 2014 when this value was 48 , it can be concluded that there is some increase, but still RM is at the bottom in Europe in respect to this data (Eurostat, 2017).

On the other hand, the number of inhabitants per one $\mathrm{CP}$ according to the estimated population number in RM for 2015 was 2448 . In 28 countries in the EU, this number is on average 3226 , with profound individual differences ranging from $~ 1000$ in Greece to 16667 in Denmark (Mlinaric et al., 2016). These differences are due to the manner of regulation for $\mathrm{CP}$ permission, where in countries with a higher number of inhabitants, demographic and geographical criteria are precisely defined, then the average and the minimum number of inhabitants per $\mathrm{CP}$, as well as the distance between pharmacies location in the urban and rural areas of the country. According to the Article 2, Regulation for the network of Healthcare Institutions in Macedonia (2012) that number is determined only according to the number of inhabitants (3000).

Detailed analysis of services, activities, infrastructure and workforce related to CPs in RM has been conducted and data are published by Arsovska et al. (2016). In order to monitor the quality of CPs activities and services it is of great importance to determine patients` satisfaction (Ford et al., 1997; Malewski et al., 2015; Zapka et al., 1995), as it can be correlated to the patients' compliance and cooperation which has impact on the quality healthcare outcomes (Martin et al., 2005). Determination of patients' satisfaction with healthcare services in general has been already performed in RM (Lazarevik and Kasapinov, 2015), but to the best of our knowledge, a specific address of patient's satisfaction with the CPs`services and activities has not been reported yet. Considering the above-mentioned facts and knowledge gap, the overall aim of this study was to investigate factors affecting patients' choice of certain CP and to overview patients impression and opinion of CPs and their roles in the healthcare system of RM. Patients also evaluated CPs premises.

\section{Material and methods}

Questionnaire structuring process, study design and methods of data collection

The cross-sectional study was approved, by the Faculty of Pharmacy, Ss. Cyril and Methodius University in Skopje, RM. In order to ensure that the design of questionnaire items would be easily and well understood by the surveyed patients, a preliminary survey was conducted on 10 adult patients in September, 2014. Afterwards, a final anonymous semi-open questionnaire consisting of 21 refined items was finalized and the survey was conducted in a period of 3 months (20.10.2014-20.01.2015) in a broad range of practice settings within the national pharmacy chain. The survey covered randomly selected patients out of those visiting CPs in all 8 regions of RM. Regions were in accordance with the division stated in the Regulation for the network of healthcare institutions (2012). There were no specific criteria for participants` study inclusion and/or exclusion. Patients were approached by trained pharmacy students 
and asked to fill in the self-administered questionnaire right after their $\mathrm{CP}$ visit in order to ensure objectivity of the collected data. All data were collected from patients that agreed to participate in the study when they were informed both, orally and in writing, about the purpose of the survey. The study covered 3 main groups of questions related to socio-demographic factors of the respondents, the reasons influencing patients choice of a certain $\mathrm{CP}$ and overview of their impressions from $\mathrm{CP}$ visit related to $\mathrm{CP}$ services and conditions as well as pharmacists expertise. Assessment of required time for medicine dispensing, CPs premises, pharmacists` professional work and expertise as well as overall impression about certain CPs and services was performed using five-point ranked Likert scale.

The results presented in the manuscript are based on the data obtained from 235 valid, analyzed questionnaires i.e. those with more than $80 \%$ of the questions answered. Each questionnaire received a unique identifier number. Obtained data were tabulated using Microsoft Excel ${ }^{\circledR}$ (Microsoft Corp. Redmond, WA, USA). All data, except age, were categorical and were given a certain rank and classified as nominal or ordinal appropriately. The data were evaluated using statistical software IBM SPSS Statistics v23 (IBM, USA). Correlation between variables of interest was established based on Spearman correlation coefficient (two tailed, $p<0.05$ ).

\section{Results and discussion}

The profile of the patients and customer in the sample size of respondents

The survey was conducted in multiple locations in $\mathrm{RM}$, where just over half $(50.64 \%)$ of the respondents were from the capital, Skopje. The age range in surveyed sample size was 15-80 years. Detailed socio-demographic factors of surveyed sample size are presented in Table 1. Female gender was prevalent in the study, similar to other studies as according to literature data women are more prone to participate in surveys (Larson et al., 2002; Lazarevik and Kasapinov, 2015; Malewski et al., 2015; Merks et al., 2014). Education level is expressed according to International standard classification of education (ISCED), while national data are sourced from the web page of State Statistical Office of the RM (www.stat.gov.mk).

Factors affecting patients' choice of a certain Community Pharmacy from the perspective of a patient and/or customer

Analyzed data show that the majority of surveyed patients $(32.48 \%)$ visit CP 2-3 times/month, $24.36 \%$ visit CP 1-2 times/week and 21.9\% more than 3 times/week, while the rest visit $\mathrm{CP}$ once or less/month. If compared to the study outcomes of Merks et al. (2014), where most of the responded patients, $62 \%$ in Poland and $61 \%$ in UK visit CPs less than twice a month and only $4 \%$ in Poland and $18 \%$ in UK 1-2 times/week, results of this study suggest that surveyed patients in RM are more frequent visitors to CPs.

When it comes to the choice of $\mathrm{CP}$, vast majority of respondents $(69.82 \%)$ always visit the same $\mathrm{CP}$, alike to UK where this value was $61 \%$ in the study of Merks et al. (2014) and 66.4\% in the study of Gammie et al. (2016). Correlation analysis indicated that patients who often visit CP (1-2 times/week and more than 3 times/week) are correlated with the choice of same $\mathrm{CP}$, while $\mathrm{CP}$ is randomly chosen by patients that rarely visit it. No correlation was found between CPs visiting frequency and gender and age.

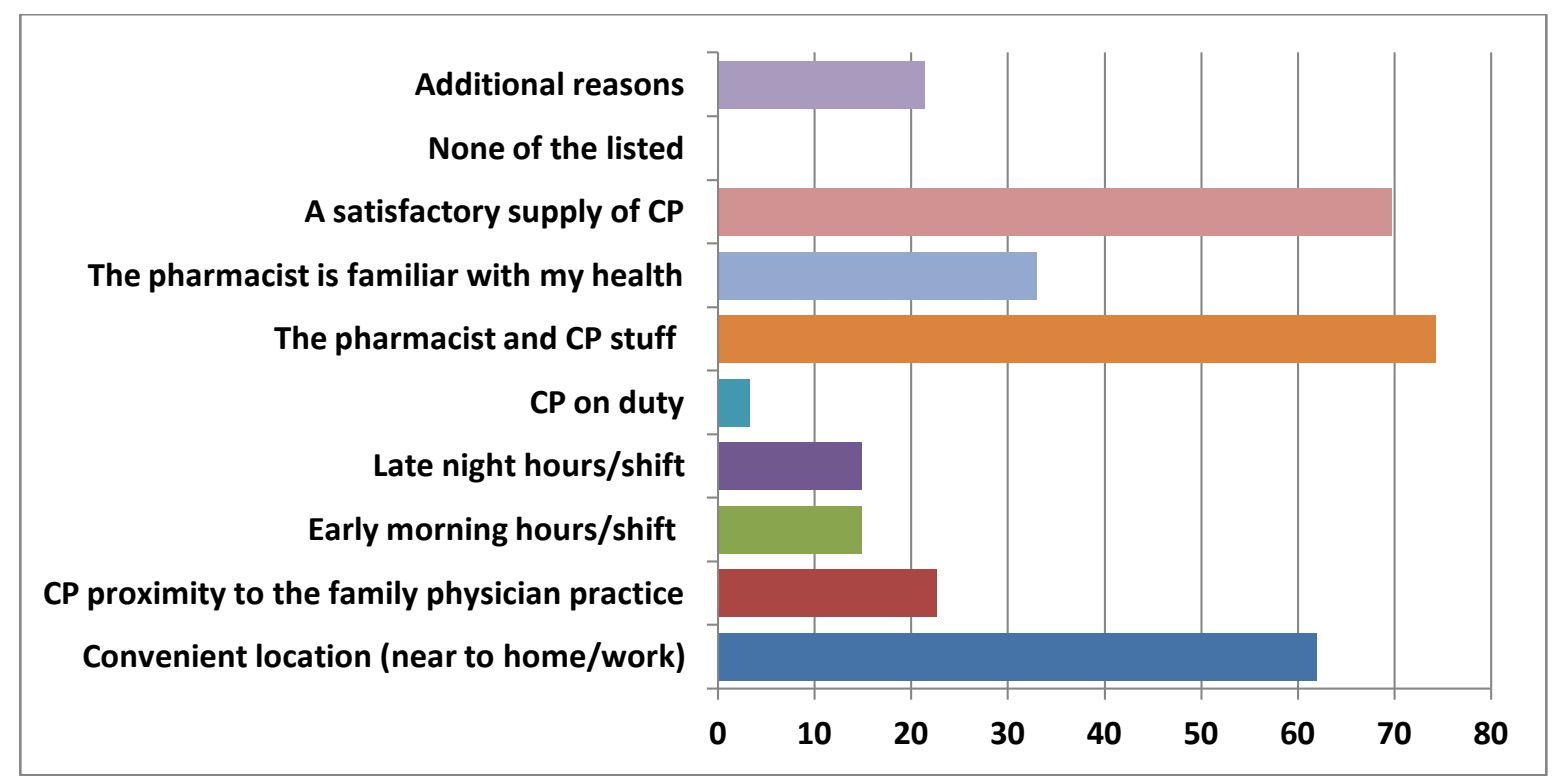

Fig. 1 Factors affecting patients` loyalty to single CP $(n=155)$.

Макед. фарм. билт., 63 (2) 3 - 10 (2017) 
Table 1. Socio-demographic factors of surveyed population $(n=235)$

\begin{tabular}{|c|c|c|c|c|}
\hline \multicolumn{2}{|c|}{ Patient/customer profile } & \multicolumn{2}{|c|}{ Study data } & \multirow{2}{*}{$\begin{array}{l}\text { National data } \\
(\%)\end{array}$} \\
\hline Factor & Description \& range & Number (\%) & $\begin{array}{l}\text { Missing } \\
\text { data }(\%)\end{array}$ & \\
\hline \multirow[t]{2}{*}{ Gender } & Female & $152(64.68)$ & \multirow{2}{*}{$1(0.43)$} & 49.91 \\
\hline & Male & $82(34.89)$ & & 50.09 \\
\hline & & $231(98.3)$ & \multirow{8}{*}{$4(1.7)$} & \\
\hline \multirow[t]{3}{*}{ average age \pm SD } & $43.76 \pm 15.53$ & & & 38.2 \\
\hline & $15-24$ & $17(7.2)$ & & 13.8 \\
\hline & $25-34$ & $62(26.4)$ & & 15.8 \\
\hline Age group & $35-44$ & $54(23)$ & & 14.6 \\
\hline \multirow{3}{*}{ (years) } & $45-54$ & $37(15.7)$ & & 14 \\
\hline & $55-64$ & $26(11.1)$ & & 12.4 \\
\hline & $>65$ & $35(14.9)$ & & 12.7 \\
\hline \multirow[t]{3}{*}{ Education level } & $\begin{array}{l}\text { Low - ISCED 0-2 } \\
\text { (elementary school) }\end{array}$ & $5(2.13)$ & \multirow{3}{*}{$4(1.7)$} & 31.5 \\
\hline & $\begin{array}{l}\text { Medium - ISCED 3-4 } \\
\text { (high school) }\end{array}$ & $116(49.36)$ & & 37.3 \\
\hline & $\begin{array}{l}\text { High - ISCED } \geq 5 \\
\text { (university) }\end{array}$ & $110(46.81)$ & & 12.1 \\
\hline \multirow[t]{3}{*}{ Employment status } & Employed & $152(64.68)$ & \multirow{3}{*}{$5(2.13)$} & 28 \\
\hline & Not working & $32(13.62)$ & & 41.2 \\
\hline & Retired & $46(19.57)$ & & 14.3 \\
\hline
\end{tabular}

In order to identify the most prevalent reasons for choosing a particular $\mathrm{CP}$, patients were offered 9 possible answers (Fig. 1) with yes and no option, and also a possibility to add additional reasons by themselves. Price of medicines was not considered as factor, as in the RM there is a Methodology for medicines' price structure (2011) and a Rulebook on the criteria and procedures to establish medicines reference prices (2009). As presented in Fig. 1, the most prevalent reasons for choosing the same $\mathrm{CP}$ were: the pharmacist and professional personnel working in a particular CP $(74.19 \%)$, CP keeps up a satisfactory supply $(69.68 \%)$ and CP is located in a convenient location (61.94\%). Furthermore, 21.29\% patients listed additional reasons aside of those already offered and hence the most common among them $(\sim 50 \%)$ were politeness and cordiality of the professional personnel. These identified reasons are akin to the study of Wirt et al. (2010).

Overview of patients' impressions after $C P$ visit related to offered services, pharmacists' expertise and CP setting conditions

The findings revealed that most often, medicines were dispensed to certain patients for their health needs, but they also revealed that the most common patient experience was to take a prescription form to the $\mathrm{CP}$ to collect someone else's medication i.e. family member, friend etc. (36.6\%, Fig. 2). According to the Law on medicinal products and medical devices (2007), Article 13, in RM all medicines depend on the practice setting and manner of dispensing are classified as those that are dispensed in a pharmacy and only on a prescription, dispensed in a pharmacy but without a prescription ("over the counter"-OTC) and those that could be used only in the hospitals. Additionally, conferring to Law on Health Insurance (2016), Article 9a, Health Insurance Fund of Macedonia does not cover the cost of all prescription medicines. Based on the survey data, solely funded prescription medicines were dispensed to $17.49 \%$ of patients, not funded prescription medicines to $4.48 \%$, OTC medicines to $19.73 \%$, herbal medicines to $15.7 \%$ and multiple types to $42.6 \%$ of the respondents.

Beside the medicines dispensing, 35.32\% of the surveyed patients visited $\mathrm{CP}$ for consultation purposes with a pharmacist $(14.89 \%)$, to buy cosmetics $(17.02 \%)$ or for both reasons $(3.4 \%)$. It was confirmed that during medicines dispensing procedure, pharmacists provided instructions for use of certain medicine written on the medicines package $(85.96 \%)$, as well as orally $(54.9 \%)$. In $67.97 \%$ of the cases pharmacists asked patients about parallel usage of other medicines and/or dietary supplements other than those dispensed at the time of $\mathrm{CP}$ visit. Also, similar percentage $(64.96 \%)$ of patients answered that if pharmacist did not ask them about the concomitant use of medicines than, in that case they would self-initiatively informed her/him about the particular issue.

In case of experiencing side and adverse medicines effect, patients, as expected, most often (74.47\%) refer for advice to the physician, but in $52.34 \%$ of the cases they 


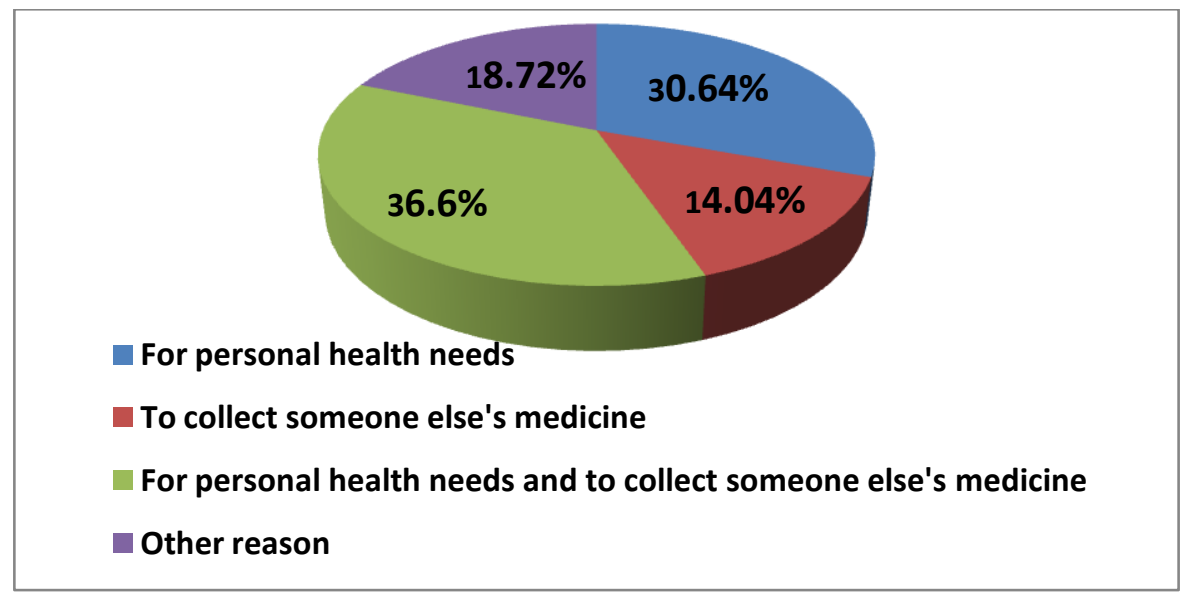

Fig. 2 Answers related to dispensed medicines to patients.

refer to a pharmacist, too. Cross tabulation of the data revealed that $32.64 \%$ of the patients refer at the same time to both the physician and pharmacist. Patients confirmed that pharmacists aside from information related to medicines usage, also, provided counseling for different health-related issues (Fig. 3). When it comes to the CPs' offered services, only $2.13 \%$ of surveyed patients reported determination of illicit medicines in urine sample, while most often they measured blood pressure $(36.6 \%)$ and blood glucose level (24.26\%).

All these data indicated that patients relatively recognized the pharmacist as a healthcare services provider, and not just as a medicines expert. However, there is a need of improving patient's knowledge about the CP services.

Having in mind that the required medicine in most cases $(84.55 \%)$ was dispensed relatively quickly, in general, patients responded that they were either very satisfied $(47.01 \%)$ or satisfied $(40.17 \%)$ with the dispensing time (positive Spearman correlation, $p<0.05$ ).

It is encouraging that elements of pharmaceutical care were highly rated by patients. Pharmacists` politeness, counseling time and attention and carefulness during patient-initiated questions at the CP (88.84\%); professional, detailed and effectual answers to questions and requests $(87.12 \%)$; the services provided by pharmacist $(87.01 \%)$; the services of the entire staff in the CP $(80.6 \%)$ as well as the efficacy of all services in the CP $(78.11 \%)$ were rated as excellent. Results related to the assessment of the professional knowledge and expertise of pharmacists are given in Fig. 4. As presented, they were most often rated as excellent, too. Additionally, $\sim 70-86 \%$ of the respondents answered confirmatory to questions related to pharmacists ' provision of information and advice regarding the proper storage and handling of medicines at home or during traveling, healthier life style and improvement of health, other healthcare services available elsewhere and allergies.

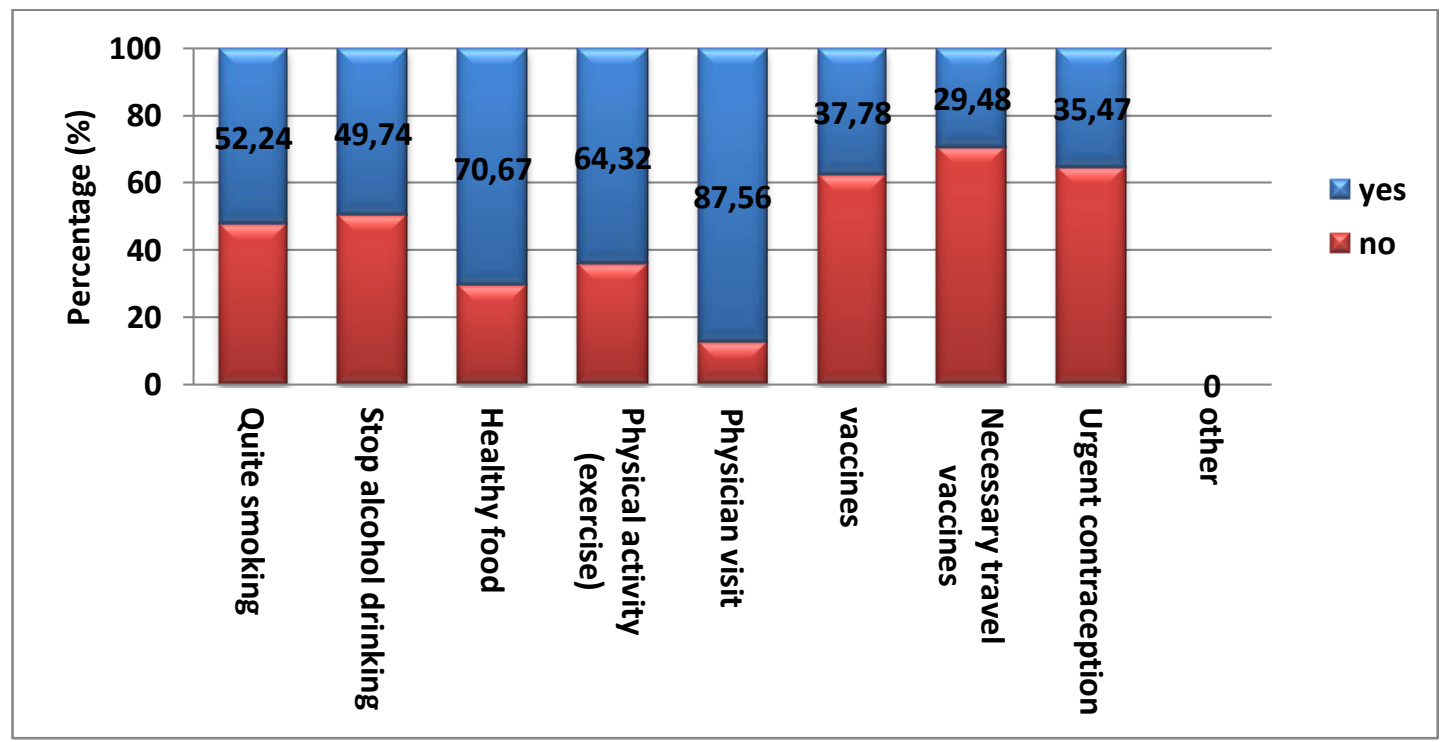

Fig. 3 Pharmacists` provided information and advices to patients aside from medicine usage.

Макед. фарм. билт., 63 (2) 3 - 10 (2017) 


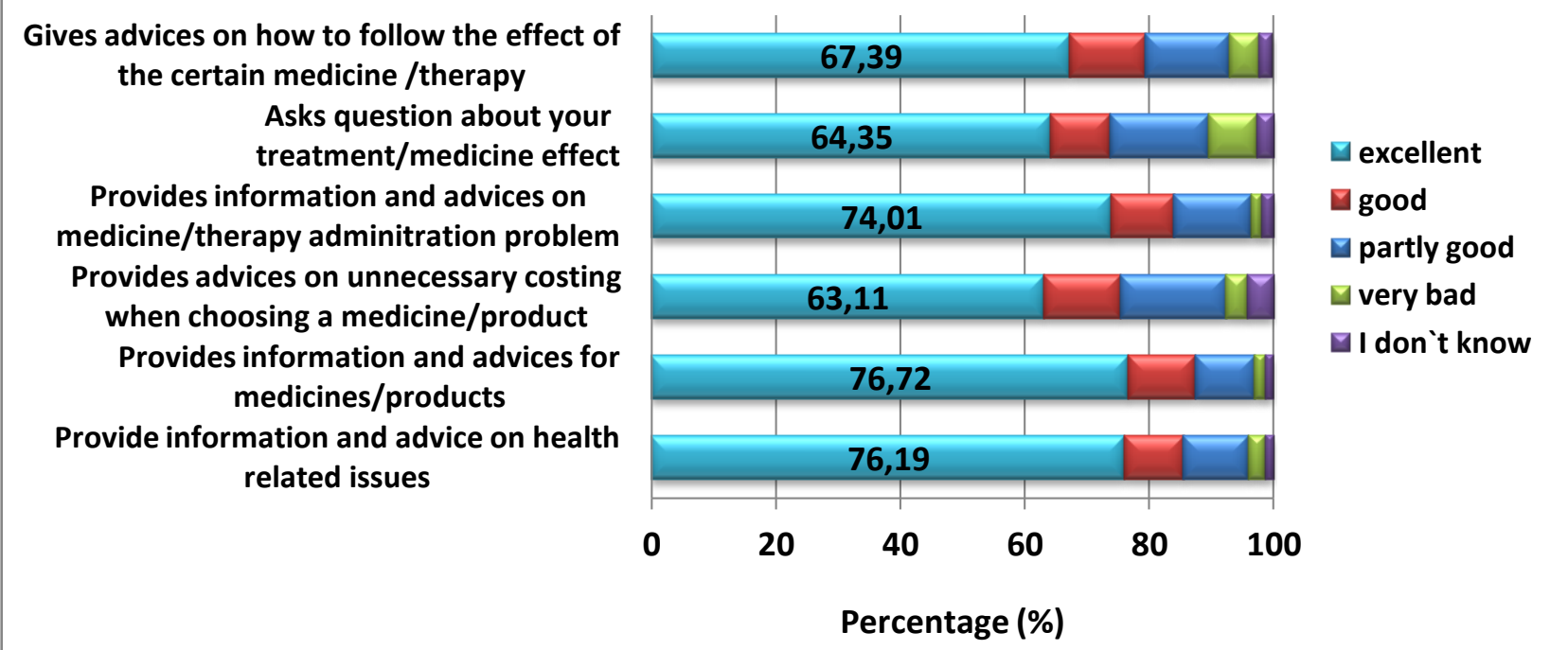

Fig. 4 Patients`assessment of the professional expertise of community pharmacist in the certain CPs.

When it comes to patients' perception related to their CP visit, the vast majority of patients $(73-86 \%)$ ranked $\mathrm{CP}$ hygienic conditions, premises, pharmacist professional attire and medicine supply as excellent. On the other hand, when it comes to respect of patients' privacy in CP only $\sim 54 \%$ rated it at the highest level and most likely this result is related to the fact that isolated consultation/counseling area is not obligatory in CPs in $\mathrm{RM}$ and only some CPs can provide a separate, designated private consultation area for certain services and sensitive counseling issues (Arsovska et al., 2016). Detailed results of patients`evaluation of certain $\mathrm{CP}$ are presented in Fig. 5. Nearly $81 \%$ of the respondents rated the certain $\mathrm{CP}$, pharmacists and services as excellent and $85.04 \%$ stated that they would visit the particular CP again.

\section{Strengths and limitations}

According to authors knowledge this study is the first in RM that addresses patient's satisfaction with CPs' services and activities. A preliminary conducted survey enabled structuring of clear and effective final questionnaire that would be acceptable for patients with open opportunity to add additional perceptions. We tried to achieve diversity in terms of the regions in RM and a degree of urbanization, thus, the study encompasses all 8 regions in Macedonia. However, out of the participating respondents, predominant input was obtained from those living in the capital of the country. The difference in surveyed population and general population in relation to socio-demographic factors is most likely due to the fact

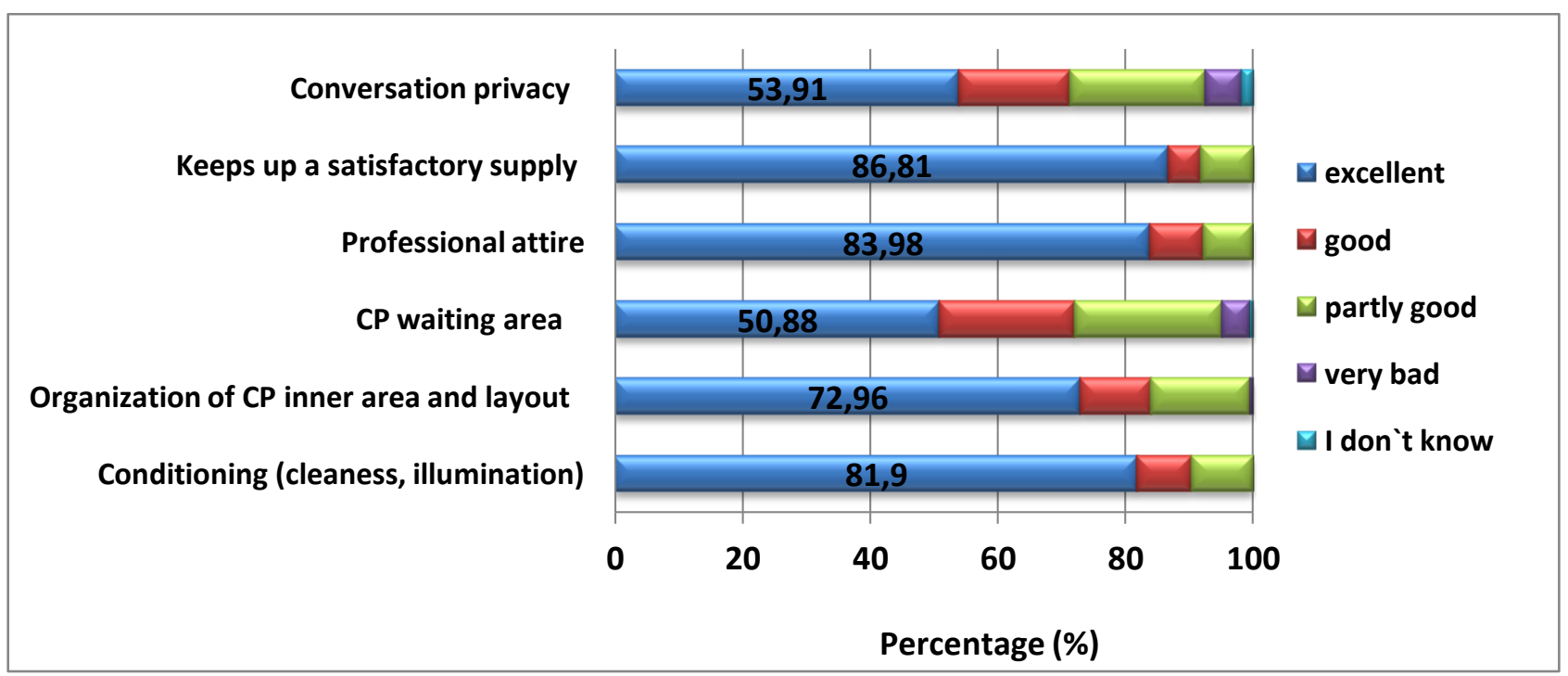

Fig. 5 Patients` evaluation of the quality of certain CP settings. 
that the study was focused on pharmacy customers during situational analysis and not on general population. Considering the reported data, the study represents patients' perception (pharmacy customers) only.

\section{Conclusion}

Community pharmacy sector has undergone many visible changes over the past decade in RM. In line with this, new contemporary practice models have been introduced in which extended role of the community pharmacist has been emerged in a range of medication-related services and expertise. For any sector of the healthcare system, patients' opinion is an important indicator of the quality of services delivered and in shaping the public's health present and future needs.

The obtained results have confirmed that patients' impressions of CPs are on a high level, i.e. they have a positive opinion. Additionally, the favorable impression that patients have of their $\mathrm{CP}$ of choice was also reaffirmed. These findings support the changing role of CPs and their contribution to patient healthcare as well as the facts that the CPs are probably the most easily accessible healthcare professionals to the public. This study can also serve as a core element for continuous monitoring and quality improvement within a national CPs network. Based on all the factors identified throughout this study, a number of recommendations can be made for $\mathrm{CP}$ services delivery in the near future.

\section{References}

Anderson, S., 2007. How British pharmacy practice is likely to be affected by changes in Europe. Pharm. J. 279, 242-244.

Arsovska, A., Simonoska Crcarevska, M., Glavas Dodov, M., Sterjeva, T., Slaveska Raicki, R., 2016. Survey of community pharmacy practice in Republic of Macedonia. Maced. Pharm. Bull. 62 (suppl), 635-636. Available at: http://bulletin.mfd.org.mk/volumes/Volume\%2062_supp/V olume_62_supp.pdf.

Chan, X.H., Wuliji, T., 2006. Global pharmacy workforce and migration report, a call for action. Available at: https://www.fip.org/files/fip/publications/PharmacyWorkfo rceMigration.pdf. Last accessed: May, 2017.

Eurostat, 2017. Available at: https://www.ec.europa.eu/eurostat/statisticsexplained/images/f/fb/HPS_Dentists\%2C_Pharmacists_and _physiotherapists_2017.xlsx. Last accessed: June, 2017.

Ford, R.C., Bach, S.A., Fottler, M.D., 1997. Methods of measuring patient satisfaction in health care organizations. Health Care Manag. 22, 74-89.

Gal, D., 2012. FIP global pharmacy, Workforce Report. Available at: https://www.fip.org/files/members/library/FIP_workforce_ Report_2012.pdf. Last accessed: May, 2017.

Gammie, S.M., Rodgers, R.M., Loo, R.L., Corlett, S.A., Krska, J., 2016. Medicine-related services in community pharmacy: public preferences for pharmacy attributes and promotional methods and comparison with pharmacists' perceptions. Patient Prefer. Adherence 10, 2297-2307. Available at: https://doi.org/10.2147/PPA.S112932.

Hepler, C.D., Strand, L., 1990. Opportunities and responsibilities in pharmaceutical care. Am. J. Hosp. Pharm. 47, 533-543.

Larson, L.N., Rovers, J.P., MacKeigan, L.D., 2002. Patient satisfaction with pharmaceutical care: update of a validated instrument. J. Am. Pharm. Assoc. (Wash). 42(1), 44-50. Available at: https://doi.org/10.1331/108658002763538062.

Law on Health Insurance, 2016. Official Gazette of the Republic of Macedonia 142/16.

Law on Healthcare, 2012. Official Gazette of the Republic of Macedonia 43/12, 145/12, 65/13, 87/13, 164/13, 39/14, 43/14, 101/14, 132/14, 188/14, 10/15, 61/15, 154/15, 17/16, $37 / 16$.

Law on medicinal products and medical devices, 2007. Official Gazette of the Republic of Macedonia 106/07, 88/10, $36 / 11,53 / 11,36 / 11,11 / 12,147 / 13,164 / 13,27 / 14,43 / 14$, $88 / 15,154 / 15,228 / 15,7 / 16,53 / 16$.

Lazarevik, V., Kasapinov, B., 2015. Predictors of patients' satisfaction with health care services in three Balkan countries (Macedonia, Bulgaria and Serbia): a cross country survey. Acta Inform. Med. 23(1), 53 -56. Available at: https://doi.org/10.5455/aim.2015.23.53-56.

Malewski, D.F., Ream, A., Gaither, C.A., 2015. Patient satisfaction with community pharmacy: Comparing urban and suburban chain-pharmacy populations. Res. Social Adm. Pharm. 11(1), 121-128. Available at: https://doi.org/10.1016/j.sapharm.2014.05.001.

Martin, L.R., Williams, S.L., Haskard, K.B., DiMatteo, M.R., 2005. The challenge of patient adherence. Ther. Clin. Risk. Manag. 1(3), 189 - 199.

Merks, P., Kaźmierczak, J., Olszewska, A.E., KołtowskaHäggström, M., 2014. Comparison of factors influencing patient choice of community pharmacy in Poland and in the UK, and identification of components of pharmaceutical care. Patient Prefer. Adherence 8, 715-726. Available at: https://doi.org/10.2147/PPA.S53829.

Methodology for medicines' price structure, 2011. Official Gazette of the Republic of Macedonia 156/11, 148/17.

Mlinaric, F., Oplotnik, Z.J., Brezovnik, B., 2016. Key Economic Parameters for an Optimal Pharmacy Network in a Regulated Environment. Transylvanian Review of Administrative Sciences 12(49), 60-77.

Regulation for the network of healthcare institutions, Official Gazette of the Republic of Macedonia 81/2012.

Rulebook on the criteria and procedures to establish medicines reference prices, 2009. Official Gazette of the Republic of Macedonia 158/09, 138/10.

Stavrova, V., Simonoska Crcarevska, M., Glavash Dodov, M., Slaveska Raicki, R., 2016. Developing community pharmacy practice. Maced. Pharm. Bull. 62 (suppl), $609-$ 610. Available at:

http://bulletin.mfd.org.mk/volumes/Volume\%2062_supp/V olume_62_supp.pdf.

Wirth, F., Tabone, F., Azzopardi, L.M., Gauci, M., Zarb-Adami, M., Serracino-Inglott, A., 2010. Consumer perception of the community pharmacist and community pharmacy services in Malta. J. Pharm. Health Serv. Res. 1(4), 189- 
194. Available at: https://doi.org/10.1111/j.17598893.2010.00034.x.

Zapka, J.G., Palmer, R.H., Hargraves, J.L., Nerenz, D., Frazier,

H.S., Warner, C.K., 1995. Relationship of patient satisfaction with experience of system performance and health status. J. Ambul. Care Manage. 18, 73-83. Available at: https://doi.org/10.1097/00004479-

\title{
Резиме
}

\section{Мислење и перцепција на пациентите за јавниот аптекарски сервис во Република Макеонија}

\author{
Маја Симоноска Црцаревска, Никола Гешковски, Марија Главаш Додов, \\ Татјана Стерјева, Кристина Караџинска, Рената Славеска Раички
}

Институт за фармащевтска технологија, Фармаиевтски факултет, Универзитет „Св. Кирил и Методиј”, Мајка Тереза 47, 1000 Скопје, Р. Македонија

Клучни зборови: фармацевти во јавни аптеки, фармацевтска грижа, мислење и перцепција на пациенти

Во текот на минатата декада во фармацевтскиот сектор на јавни аптеки (JA) во Р. Македонија (PM) се случија големи промени. Целта на оваа студија беше да се направи увид и анализа на перцепцијата и мислењето на пациентите во однос на ЈА секторот и неговата препознатливост во рамки на здравствениот систем на РМ. Дополнително, студијата беше фокусирана и на факторите што влијаат на изборот на одредена ЈА од страна на пациентите и нивната перцепција во однос на инфраструктурата на JА. Во истражувањето беа опфатени случајно избрани пациенти при посета на JA во сите 8 региони на РМ. За таа цел беше дизајниран анонимен полуотверен прашалник што се состоеше од 21 прашање поделени во три главни групи кои се однесуваа на: социјалнодемографските податоци за испитаниците, причините што влијаат на нивниот избор на одредена ЈА и нивното мислење и впечатоци за експертизата на фармацевтите во JA и услугите во истите. Резултатите покажаа дека $69,82 \%$ од испитаниците секогаш посетуваат иста ЈА, при што најчестите причини се: (1) фармацевтот и останатиот персонал кои работат во JA $(74,19 \%)$, (2) JА има задоволителна снабденост $(69,68 \%)$ и (3) JA се наоѓa на соодветна локација $(61,94 \%)$. Генералната перцепција на пациентите за услугите во делот на фармацевтската грижа во JA беше дека истите се на високо ниво (над 80\%). Направената студија може да послужи како основа за континуирано следење и подобрување на квалитетот на услугите во мрежата на JА во РМ во иднина. 